From this evidence we conclude that treatment of Cohn's fraction I + II + III with concentrated salt solutions brings about the loss of some lipid components from the $\beta$-lipoproteins, with the formation of substancos of higher density (compare Hayashi, Lindgren and Nichols ${ }^{8}$ ). Furthormore, it seems highly probable that the 'high-density $\beta$-lipoproteins', which woro originally observed during the sub-fractionation of I + II + III, woro also artefacts formod in this way. It also follows that the different results obtained by the ultracentrifugal and chemical techniques for separating lipoproteins must be ascribed to deficiencies in the methods and not to the presence of lipoproteins of bizarre properties. It may also be observed that the 'high-density $\beta$-lipoprotein' was suggested by Lindgren and Nichols ${ }^{10}$ to be evidoneo for different lipoprotein spectra in fraction I + II + III and in the low-density group. This postulate now appears to be superfluous, at least in tho caso of normal plasma.

These experiments suggest that, although the Cohn fractionation technique does not itself cause damage to the lipoproteins, it can potentiate unstablo characteristics which become manifest during subsequent treatment. It is therefore not a good starting point for the preparation of intact lipoproteins, but may be a useful route to the preparations deficient in lipids which are required for investigations of lipoprotein structure.

We thank Sir Charles Dodds for encouragement, and the British Heart Foundation for support.

$$
\begin{aligned}
& \text { G. L. Mills } \\
& \text { C. E. Taylaur } \\
& \text { Patricia A. Wrukinson }
\end{aligned}
$$

Courtauld Institute of Biochemistry,

Middlesex Hospital Medical School, London, W.I.

${ }^{2}$ DeLalla, O., and Gofman, J. W., Methods of Biochemical Analysis, 1, edit. by Glick, D. (Interseience, New York, 1954).

2 Cohn, E. J., Gurd, F. R. N., Surgenor, D. M., Barnes, B. A., Brown, R. K., Derouaux, G., Gillicspic, J. M., Kahnt, F. W., Lever, W. F., Liu, C. H., Chem. Soc., 72, 465 (1950).

- Barclay, M., Cogin, G. E., Escher, G. C., Kaufman, R. J., Kidder, E. D., and Peterman, $M$. $I$, Cancer, 8, 253 (1955).

- Carlson, L. A., Clin. Chim. Acta, 5, 528 (1960).

s Mills, G. I., and Wilkinson, P. A., Clin. Chim. Acta, 8, 701 (1963).

- Ray, B. R., Davisson, E. C., and Crespi, H. T., J. Amer. Chem. Soc., 58 841 (1954).

"Peterman, M. L., Barclay, M., Escher, G., and Kaufman, R., The Lipoproteins, Methods and Clinical Significance, edit. by Homburger, F, and Bernfeld, P. (S. Karger, New York, 1958).

- Hayashi, S., Lindgren, F'., and Nichols, A., J. Amer. Chem. Soc., 81, 3793 (1050).

'Brown, R., deLalla, L., and Kauffman, D., Clin. Chim., 1, 83 (1055).

${ }^{10}$ Lindgren, F., and Nichols, A. V., The Plasma Proteins, 2, edit. by Putnam, F. W. (Academic Press, New Ÿork, 1960).

\section{Glycolyl-neuraminic Acid in Ox Brain Gangliosides}

IN this communication we report the presonce of glycolyl-nouraminic acid in sialic acids from ox brain gangliosides. Our method of analysis consisted of the following six steps: (i) gangliosides were extracted from ox brain groy mattor and purified according to a mothod which we have previously described ${ }^{\mathrm{I}}$; (ii) gangliosides so obtained were hydrolysed in $0.1 \mathrm{~N}$ sulphuric aeid at $80^{\circ} \mathrm{C}$ for $2 \mathrm{~h}$, to split off sialic acid; (iii) sialic acid was purified on 'Dowex' $2 \times 8$ column as acetate according to Svennerholm', and dosalted on 'Amberlite $I R-120$ '; (iv) tho solution was driod in vacuum and tho residue was hydrolysed in $1 \mathrm{~N}$ sulphuric acid for $5 \mathrm{~h}$ at $100^{\circ} \mathrm{C}$ to obtain glycolie acid ${ }^{3}$; (v) glycolic acid was purified on 'Dowex' $2 \times 8$ column as acetate and eluted with $\mathrm{NaCl}$ $2 \mathrm{M}$; (vi) the glycolic acid was identified by the Eegriwe rouction ${ }^{4}$ and by gas-chromatography.

Tho following proceduro was used for tho gas-chromatographic analysis: glycolic acid was extracted from the $2 \mathrm{M} \mathrm{NaCl}$ solution by chloroform-mothanol $7: 3(\mathrm{v} / \mathrm{v})$.

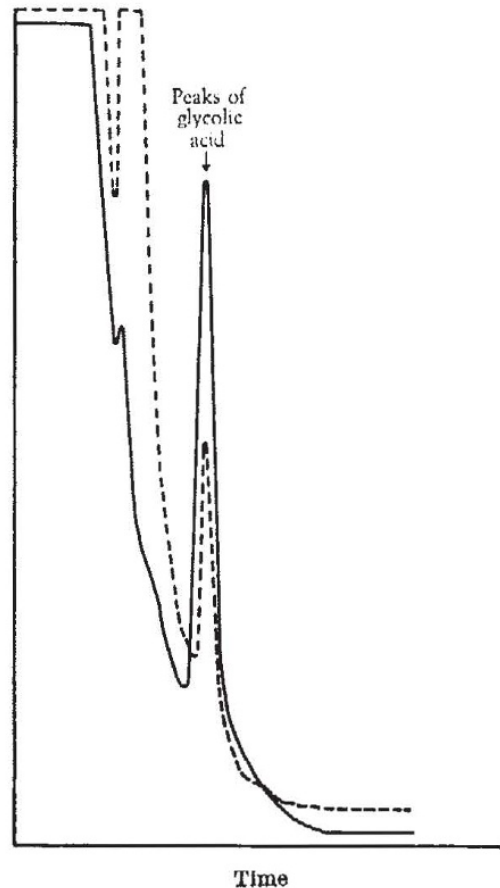

Fig. 1. Gas chromatogram of propylated glycolic acid. Solid line, pure glycolie acid (propylated); broken line, glycolic acid from ganglioside

The solution was dried in vacuum and the glycolic acid contained in the residue was propylated by propanol saturated with $\mathrm{HCl}$ at $70^{\circ} \mathrm{C}$ for $10 \mathrm{~min}^{3}$. A standard of pure glycolic acid (propylated in the same way) and the solution under analysis wore then gas-chromatographed ${ }^{3}$. Good correspondence was obtained between the peaks of pure and extracted glycolic acid, as shown by the gaschromatograms given in Fig. 1. The amount of glycolylneuraminic acid was calculated from the glycolic acid content (obtainod by the Eegriwe reaction mothod) and found to represent 2-4 per cent of the total sialic acids contained in ox brain gangliosides.

This work was supported by a grant from the Consiglio Nazionale delle Ricerche, and the Amministrazione Provinciale of Milan.
G. Thtmamanti
I. BERTONA
B. BerRa
V. ZAMBOTTI

Department of Biological Chemistry, University of Milan.

2 Tettamanti, G., Bertona, L., Berra, B., and Zambotti, C., Giornale Ital. Biochim., 13, 326 (1904).

2 Svennerholm, L., Biochim. Biophys. Acta, 14, 604 (1957).

Tettamanti, G., et al., Istituto Lombardo (rend. Sc.), B, 97, 157 (1968)

- Eegriwe, E., Z. Anal. Chem., 88, 123 (1032).

\section{Precipitation of Pertussis Immunogen with Benzathene and Proflavine}

Two years ago I described a mothod for obtaining soluble preparations of pertussis mouse protective antigen (immunogen) by lysing the bacterial cells with sodium dooxycholate ${ }^{1}$. I now wish to report the partial purification of these extracts, using the organic bases benzathene and proflavine as precipitating agents. In a typical exporimont with the former, deoxycholato lysato of pertussis derived from a cell concentration of 320 opacity units (OU) per ml. was treated dropwise at $p H$ 7.4-7.5 at room temperature with a 14 por cent $(w / v)$ solution of benzathene (dibenzylethylene diamine acetate). The mixture was shaken continuously and its optical density monitored until maximum density, indicative of maximum 